\title{
The Kaali crater field and other geosites of Saaremaa Island (Estonia): the perspectives for a geopark
}

\author{
Anto Raukas ${ }^{1} \&$ Wojciech Stankowski ${ }^{2}$ \\ ${ }^{1}$ Institute of Ecology, Tallinn University, Uus-Sadama 5, 10120 Tallinn, Estonia;e-mail: anto.raukas@mail.ee \\ ${ }^{2}$ Institute of Geology, Adam Mickiewicz University, Maków Polnych 16, 61-606 Poznan, Poland; \\ e-mail: stawgeo@amu.edu.pl
}

\begin{abstract}
The Island of Saaremaa in Estonia offers highly spectacular geological features that belong to the most interesting in the Baltic Sea area. A unique geological monument on the island is the Kaali meteorite-crater field, formed by nine meteorite impacts. There are also attractive coastal cliffs, huge erratics, alvars (limestone areas covered by a very thin soil) and well-developed glacial and marine landforms. Limestone cliffs and shingle beaches abound with Silurian fossils and offer great opportunities to fossil collectors. The island is a prospective geopark. During the past few years, the geology of the island has become an intensely studied object of Estonian and Polish geologists.
\end{abstract}

Keywords: geopark, geosites, meteorite-crater field, Saaremaa Island, Estonia

\section{Introduction}

The Island of Saaremaa (Ösel in German and Swedish) is one of the largest islands in the Baltic Sea, measuring 2,673 $\mathrm{km}^{2}$. It belongs to the West Estonian Archipelago. The island has a low population density, with only about 40,000 people.

Like the whole Estonian territory, Saaremaa is located on the southern slope of the Fennoscandian Shield and the peripheral part of the East European Platform, built of Lower Palaeozoic strata. The geological structure is, in combination with morphogenesis, responsible for an interesting landscape. Spectacular are tectonics-related seashore cliffs. Glacial topography formed mainly during the glaciation, whereas young abrasion forms were created during various phases of the Baltic Sea devel- opment. Worldwide importance has the Kaali crater field, the first one in Europe of which this origin was scientifically proven by finds of meteoritic iron. The geological/morphological characteristics of the island, in combination with the peculiar flora and fauna, together with the archaeological, historical and cultural heritage deserve to be preserved in the form of a geopark.

\section{Geological setting}

Saaremaa is located on the southern slope of the Fennoscandian Shield, which is composed of crystalline rocks that actually form a southward extension of the Precambrian complexes that crop out in southern Finland. The surface of the Fennoscandian Shield dips slightly 


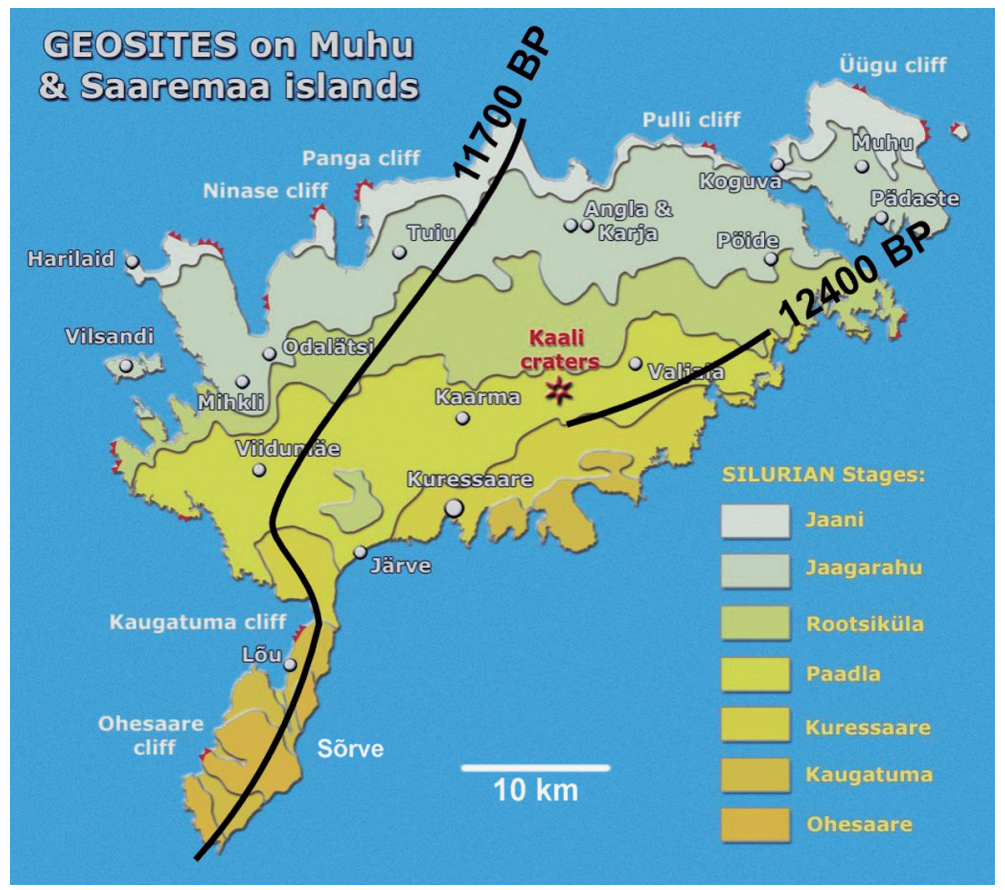

Fig. 1. Bedrock map of the Saaremaa and Muhumaa islands (from material of the Estonian Geological Survey) with the most important geosites (compiled by Heikki Bauert). Ice-marginal zones date from 12,400 years BP (Pandivere Stadial) and 11,700 years BP (Palivere Stadial). After Raukas \& Stankowski (2005). southwards, with about $3.2 \mathrm{~m} / \mathrm{km}$. Based on borehole data and geophysical evidence, the crystalline rocks occur in Saaremaa at a depth of several hundreds of metres; the 500-metre isobath runs through the central part of Saaremaa in a roughly W-E direction. The Proterozoic formations are represented by several types of magmatic and metamorphic rocks (Perens, 2002).

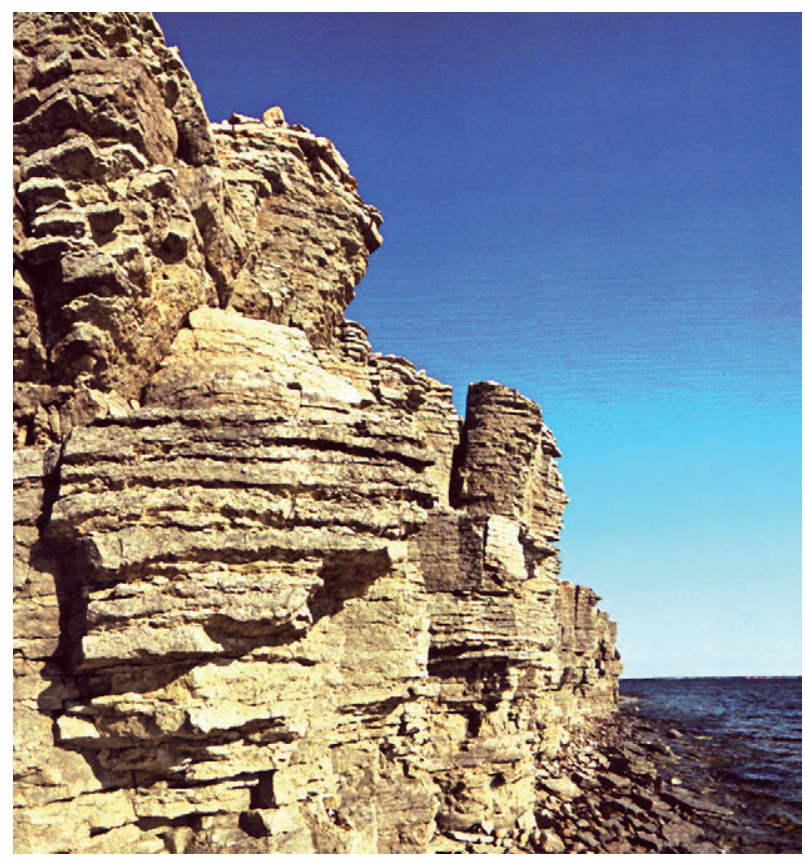

Fig. 2. Silurian carbonate rocks of the Ninase cliff at the northern shore of Saaremaa (photo by H. Bauert).
Most of Saaremaa is located within the folded Latvian-Estonian basement complex, which is 1.9-1.8 Ga old. The northern edge of this complex is marked by the somewhat younger (1.6-1.55 Ga) Riga rapakivi pluton, which extends to the south-western corner of the island. Eastern Saaremaa consists predominately of metamorphic rocks, while acid igneous rocks (mostly different types of granites) dominate in the western part of the island.

Cambrian rocks are not exposed anywhere but are known from drilling cores. The exposed limestones and dolostones are of Silurian age. The boundary between Lower and Upper Silurian carbonate rocks (between the Rootsiküla and Paadla regional stages) runs through central Saaremaa (Fig. 1). The youngest Silurian rocks - limestones of the Ohesaare Stage, which formed approx. $417 \mathrm{Ma}$ ago - crop out in the south-western cliffs of the Sõrve peninsula, southernmost Saaremaa. The total thickness of the Silurian succession is impressive, reaching $445.7 \mathrm{~m}$ according to core data from the Ohesaare drill site. It consists of 10 chronostratigraphical units (stages). The Juuru, Raikküla, Adavere, Jaani, Jaagarahu and Rootsiküla stages belong to the Lower Silurian succession, whereas the Paadla, Kuressaare, Kaugatuma and Ohesaare stages constitute the Upper Silurian succession (Perens, 2002). 
The Silurian carbonate rocks of Saaremaa are rich in fossils. Several Silurian limestone and dolostone varieties are not only good building stones, but are also highly valued as excellent source material for the manifacturing of natural finished stone products. For instance, the Upper Silurian Selgase mottled, easily handled limestone is widely used not only for limestone carvings (cups, plates, candlesticks) but also for the production of finished natural stone objects such as fireplace parts, wall blocks and wall veneers. For centuries, impurity-free, chemically pure limestone has been used for burning high-quality lime. This kind of limestone was mined at the Jaagarahu limestone quarry North of Kihelkonna village in NW Saaremaa.

\section{Landscape}

Spectacular are the numerous seashore cliffs, which actually are coastal escarpments eroded into carbonate bedrock by waves (Märss et al., 2007). The Saaremaa cliffs display a variety of shapes: some of them stand as almost vertical walls (Panga cliff) but other cliffs look as scarps with wave-cut notches in their lower part (Üügu cliff). There are also cliffs rising in the form of terraces towards the land. The cliffs should be considered as active phenomena, descending straight into the sea and subjected to direct wave action (Fig. 2), but farther inland also 'fossil' cliffs exist. These are coastal scarps formed during earlier stages of the Baltic Sea development.

The height of the cliffs varies considerably, ranging from only a few to $21.3 \mathrm{~m}$ for the Panga (Mustjala) cliff. Vertically uprising steep walls have developed in carbonate rocks of uniform resistance to erosion and weathering. Wave-cut notches are characteristic for the lower parts of cliffs that consist of more argillaceous carbonate rocks. The latter are less resistant to marine erosion than the more pure limestones.

Some ten million years ago, the whole Baltic area was emerged, reaching considerable absolute heights, and dissected by giant rivers cutting deep into the rocks. Erosion caused the formation of deep valleys in the Sõrve penin- sula (the limestone bedrock lies $92.5 \mathrm{~m}$ below sea level at Mõntu).

The glacial topography of the island stems mainly from the last glacial. Large, massive continental glaciers derived from the Scandinavian mountains transported a large number of erratics to Saaremaa; some of them are truly huge (Raukas, 1995). The glacial and glaciofluvial sediments are fairly thin and reworked to a large extent by the waters of the Baltic Sea. Waves strongly eroded the emerging land and, in some places, changed the originally icesculptured landscapes beyond recognition. The most magnificent glacial landform is without any doubt the West-Saaremaa Upland, a huge end moraine composed mainly of till and rising 20-35 $\mathrm{m}$ above its surroundings. The WestSaaremaa Upland owes its characteristics to its position between two ice flows, which moved in different directions and which were not simultaneous (Karukäpp et al., 2002). The most recent glacier moved from north-west to southeast and carried erratic boulders to western Saaremaa; these boulders differ in composition from those found in eastern Saaremaa (Raukas, 1995). The southern extension of the WestSaaremaa Upland is the Sõrve Upland.

The other glacial landforms of Saaremaa are of a much smaller scale. Some glacial accumulations in Saaremaa are reflected by the hilly landscape near Pöide and Valjala. The largest glaciofluvial landforms are represented on the West-Saaremaa Upland near Viidumäe (for instance at Kodaramägi) and on the Sõrve peninsula (for instance at Viieristi).

\section{Post-glacial history}

The deglaciation history of Estonia (see Fig.1) has been dated using radiocarbon, varvechronology, palynology, electron spin resonance, thermoluminescence, optically stimulated luminescence and cosmogenic-beryllium methods. The results are highly heterogeneous (Raukas, 2009). During the past few years, the present authors studied the suitability of luminescence (TL and OSL) dating techniques for establishing a precise Late Pleistocene chronology for the Baltic area (Raukas \& Stankowski, 
2005). It turned out that, in addition to reliable dates, many entirely unreliable dates were thus obtained, but the Late Pleistocene history could nevertheless be reconstructed. When the land-ice cap had retreated from the area, the surface started to rise rapidly as a result of glacioisostatic adjustment of the Earth's crust: the land was elevated in the order of $40-50 \mathrm{~m}$. The ice-freed areas became almost completely inundated by waters of local ice-dammed lakes. The lowering of the water level in the glacial lakes was controlled by the velocity and extent of the ice-sheet retreat. This retreat was not uniform in time: occasionally short-term re-advance of glacier tongues took place, accompanied by a rise in the water level.

After the retreat of the continental ice sheet, Saaremaa was flooded by waters of the vast Baltic Ice Lake. Four islets in the area now covered by Saaremaa (two in the area which is now the West-Saaremaa Upland and two at the present-day Sõrve peninsula) emerged from the sea approx. $10,300-10,200{ }^{14} \mathrm{C}$ years ago, when meltwaters of the Baltic Ice Lake eroded a pathway to the ocean through central Sweden. As a result of this breakthrough, the level of the Baltic Ice Lake was lowered by 20-30 m, to ocean level. Water exchange with the Atlantic Ocean was established and this led to the development of the weakly saline Yoldia Sea, which existed for about 900 years. During this timespan, large areas of Saaremaa emerged.

\section{Relative sea level}

As a result of the continuing glacioisostatic uplift, the area of Saaremaa expanded, and this process is still going on. During the phases of the Ancylus Lake $\left(9300-8000{ }^{14} \mathrm{C}\right.$ years ago) and the Litorina Sea $\left(8000-4000{ }^{14} \mathrm{C}\right.$ years ago), several transgressions occurred. The first one culminated approx. 9200-9000 years ago, when the sea reached a height of $35 \mathrm{~m}$ above the present-day sea level on the slopes of the West-Saaremaa Upland. Coastal formations accumulated in the Litorina Sea represent five transgression phases. These transgressive coastal formations occur at a height of 21 $\mathrm{m}$ above sea level in north-western Saaremaa, and at a height of $15 \mathrm{~m}$ on the Sõrve peninsula. The transgressive coastal forms are impressive, because the water-level rise kept more or less up with the uplift of the land, so that accumulation of shoreline deposits in a narrow zone could proceed for a long time.

About $4000{ }^{14} \mathrm{C}$ years ago, the sea level started to drop slowly. This was caused by a climate cooling that also induced ice-sheet growth in the polar regions. As a result, the Danish Straits became shallower, and the inflow of saline water into the Baltic Sea diminished. This, still ongoing brackish-water stage of the Baltic Sea is called the 'Limnea Sea'. The oldest coastal formations of the Limnea stage on Saaremaa are known from a height of 5-11 $\mathrm{m}$ above present-day sea level.

Different shore types (cliffs, rocky, morainic, sandy, shingle, silty) and accumulative forms (such as spits, bars, coastal dunes), are scattered over the island and are protected as geological monuments .

\section{The Kaali crater field}

The Kaali site is one of the most important places of morphogenetic interest in Europe. The Kaali crater field (Fig. 3), about 19 km NE of the town of Kuressaare consists of a main crater surrounded by eight secondary craters and covers an area of about $1 \mathrm{~km}^{2}$, as the result of a small meteorite shower. This meteorite shower is one of very rare cosmic catastrophes of this magnitude that took place in Europe in historical time.

\section{Meteorite characteristics}

The meteorite represents the most common type of iron meteorite, a coarse octahedrite, which contains $91.5 \% \mathrm{Fe}$ and $8.3 \% \mathrm{Ni}$, with $\mathrm{Co}$, Ge and Ir as admixtures, and contains minerals characteristic of iron meteorites such as shreibersite, kamasite and taenite (Marini et al., 2004). A polished surface of the meteorite displays the typical Widmanstätten's structure. The meteorite fragments found in Kaali are small, with an uneven surface and sharp 
edges, with a weight of $0.5-2 \mathrm{~g}$. The surface of the fragments has become oxidised over time and is covered with rust. Presently, strict rules have been established for those searching for meteorite fragments, because the excavation activities carried out to date have considerably affected several craters.

\section{Origin and characteristics of the craters}

The main crater, 105-110 $\mathrm{m}$ in diameter, attracted natural scientists already in the first half of the $19^{\text {th }}$ century. Johan Wilhelm Ludwig von Luce (1756-1842) explained the formation of the crater "after the explosion of the underground fire". During the past hundreds of years, several studies on the Kaali main crater have been published, explaining its origin as (1) a subterranean fire or phreatomagnetic explosion, (2) a volcanic eruption or abrupt emission of water, steam, gas and mud, (3) the collapse of a karst cave due to limestone fissuring, or collapse of a salt dome, (4) an ancient stronghold, where the natural lake served as a well that was later surrounded by man-made walls, and (5) a meteorite crater.

Now, there is no doubt anymore that the Kaali craters are of meteoritic origin. The energy needed for the formation of the main crater is traditionally estimated as $4 \times 10^{19}$ ergs. The meteorite was about $4.8 \mathrm{~m}$ in diameter and its mass was some $450,000 \mathrm{~kg}$; its impact velocity was $21 \mathrm{~km} / \mathrm{s}$ (Tiirmaa, 1994). The uplifted, tilted and highly destroyed dolostone blocks on the slopes of the main crater (Fig. 4) demonstrate clearly an upward explosion direction.

\section{Crater research}

Up to the mid-70's of the last century, the craters were investigated mainly by geologists. Later, historians and botanists joined them. Lennart Meri, writer and former president of Estonia, analyzed in his books the possible influence of the Kaali catastrophe on human recollections. He tied together disputed historical tidbits, linguistic expressions and his
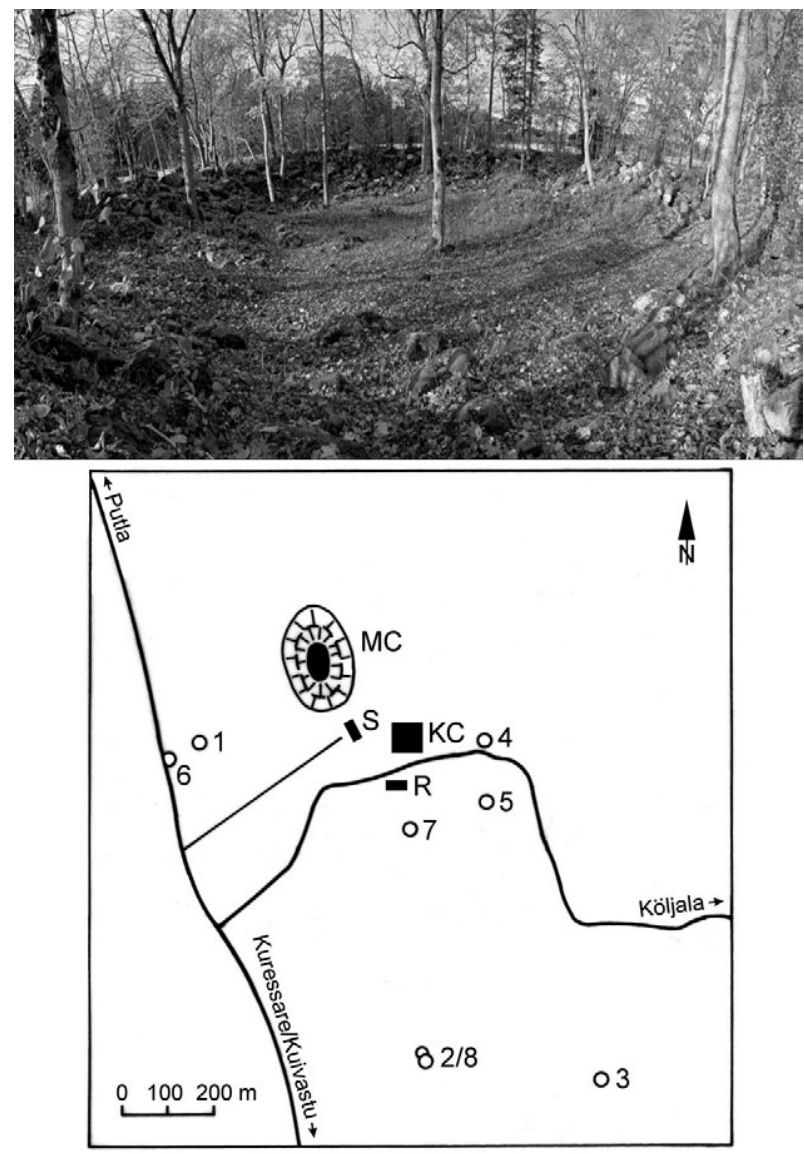

Fig. 3. The Kaali meteorite craters field.

MC - main crater with a lake inside; 1-8 - small craters; S - schoolhouse; KC - conference center (museum, hotel); R - restaurant.

own thoughts into an interesting whole (Meri, 1976).

In the 1970s, archaelogical excavations were begun in the old fortification that was discovered on the outside slope of the northern wall of the main crater. Most artefacts date from the Iron Age. During the 1976-1978 excavations,

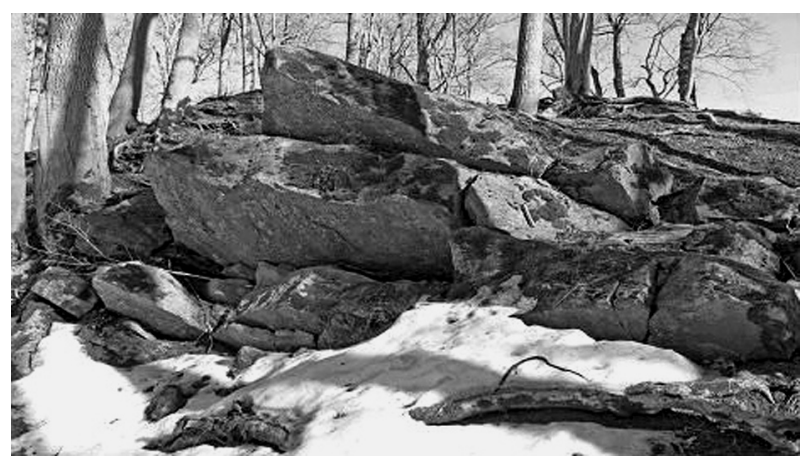

Fig. 4. Uplifted dolostone blocks in the main crater (photo by R. Tiirmaa). 
archaeologists found animal bones in Lake Kaali in peat layers of over 1500-2000 years old; these bones are believed to be remnants of religious sacrifices. Detailed specialist studies of extraterresrtial matter mineralogy were carried out as well (Marini at al., 2004; Raukas, 2004; Uścinowicz, 2008).

The morphology of the main crater has been well studied (Raukas et al., 2005). The average depth of the main crater, from the top of the mound down to the mud layer on the lake's floor, is $16 \mathrm{~m}$. Considering the maximum thickness of the lake sediments, the depth of the crater may be some $22 \mathrm{~m}$. The somewhat irregular shape of the crater wall can be explained by the uneven ejection of material as a result of the angle of incidence of the meteorite, but human impact during many centuries may also play a role. Fortunately, the crater is located in hard carbonate rocks, and its main morphological features have ben well preserved (Fig. 5).

On the base of 98 borings and several purposely dug excavations, new information about the lithology of the crater filling deposits was recently obtained (Moora et al., 2008). The correlation of the various boreholes is complicated due to reworking of the material filling the crater. For instance, a heap of large stones has been positioned at the centre of the lake bottom as a monument for a deceased owner of the estate. In addition, the large number of visitors and natural processes have facilitated the erosion of the crater slope and accelerated the accumulation of sediments in the lake-filled

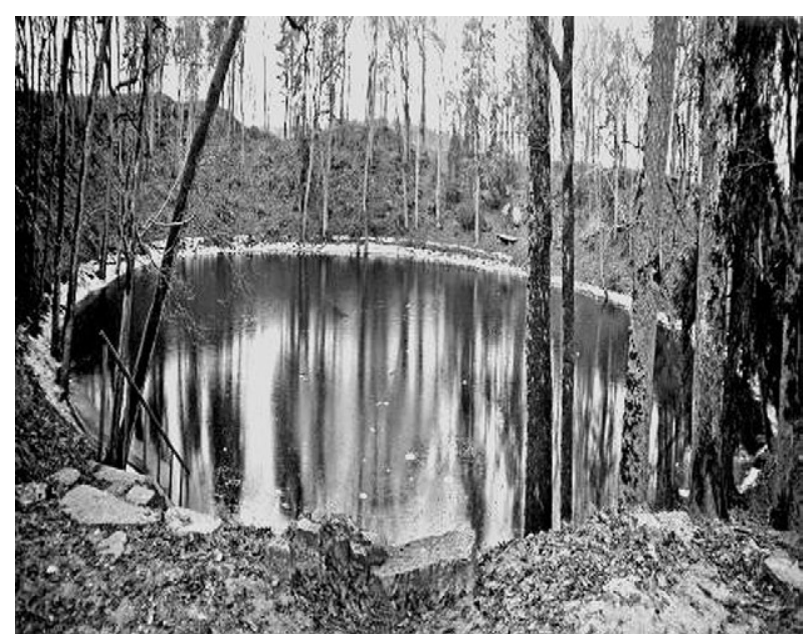

Fig. 5. Lake Kaali in the main crater (photo by R. Tiirmaa). depression. Reworked and in situ material have commonly become mixed, so that the palynological spectra are difficult to interpret.

\section{Date of the impact}

The age of the Kaali craters is still under discussion as the various data are inconsistent. It is agreed, however, that the craters were formed after the retreat of the Baltic Sea from this part of Saaremaa (possibly during the very last phase of the retreat: see the luminescence data of the infilling of crater 7). This implies that they are younger than 8500 years. The pollen spectrum from the bottom deposits of Lake Kaali has been dated as approx. 3700 years old. Radiocarbon datings have yielded an age of about 4000 years (Raukas et al., 2005). Based on the findings of silicate spherules in the peat layer in the bogs surrounding the craters, it might be deduced that the craters formed 7500-7600 years ago (Raukas, 2004).

On the basis of the above data, it is obvious that the craters are older than 4000 years. This implies that many of interesting legends about the origin and age of the craters (Veski et al., 2001), like the burning of ancient strongholds at Asva and Ridala due to an impact at about 2600 years ago, are scientifically not tenable.

If the meteorite had pierced the dolostone rocks at the surface, the impact must have been accompanied by the setting free of heat which must have turned the water in the rocks instantaneously into steam; it must also have heated the gases. They must have caused burning of the rock not only to the depth reached by the impactor, but also at much greater depths, thanks to the dense net of impact-generated cracks.

The high temperatures and pressures occurring during the meteorite impact must have induced bleaching, and the luminescence ages should therefore coincide with the age of the craters. The first investigations in the Kaali main crater $(5.8 \pm 0.6$ and $5.6 \pm 0.9$ ka TL) and small craters are therefore very promising (Stankowski et al., 2007). 


\section{Description of the secondary craters}

The eight small secondary craters in Kaali are mostly dry; their diameters range from 12 to $40 \mathrm{~m}$ and their depth from 1 to $4 \mathrm{~m}$. Studies of the secondary craters have provided valuable information about the meteorite shower that could not have been obtained from the main crater alone. Due to Estonian-Polish cooperation, TL and OSL measurements from the secondary craters of the Kaali impact could be realized.

Crater 1 is a depression that is overgrown with shrubs. The crater has a diameter of 39 $\mathrm{m}$ and is $4 \mathrm{~m}$ deep. Uplifted dolostone layers are exposed here, as in the main crater. Erratic boulders from the field have been carried into the crater and onto the rim. The crater is easily visible in the middle of cultivated land as a evenly rounded group of trees. Two TL dates, $5.8 \pm 0.9 \mathrm{ka}$ (bleaching connected to impact) and $11.4 \pm 2.6 \mathrm{ka}$ (time of the sediments' origin, in this particular case not bleaching) have been obtained for the proximal slope of the rim, segment $\mathrm{S}$. The data of $\sim 11 \mathrm{ka}$ BP for non-bleached material correspond well to the known time of last ice retreat from North-West Estonia. The correctness of this luminescence dating was successfully verified by us through a sample age from Salpausselkä near Ekenes (Finland), which was $10.34 \pm 0.82 \mathrm{ka} \mathrm{(Gd} \mathrm{TL} \mathrm{930).}$

Twin craters 2 and 8 were formed by the impact of two separate meteorite fragments. The traces left behind are located very close to each other, thus forming one depression with a somewhat complex outline. The northern crater (no 2) is $27 \mathrm{~m}$ in diameter and $2 \mathrm{~m}$ deep, and the southern one (no 8 ) is $36 \mathrm{~m}$ wide and $3.5 \mathrm{~m}$ deep. The longitudinal axis of the twin crater is $53 \mathrm{~m}$. In 1937, the first 28 meteorite fragments (total weight $102.4 \mathrm{~g}$ ) were found in this twin crater (Reinwaldt, 1938). Excavations have considerably altered the craters' preliminary appearance; the crater rim is barely visible anymore. From the top part of the rim, segment $S$, a TL date of $9.8 \pm 2.3$ and an OSL date of $8.7 \pm 078$ ka have been obtained. A sample from about $40 \mathrm{~m}$ to south of the rim, at a depth of $60 \mathrm{~cm}$, yielded an OSL date of $4.25 \pm 0.32 \mathrm{ka}$.
Crater 3 is the best preserved, and forms a clearly visible secondary crater. The crater is surrounded by hazel shrubs and measures 33 $\mathrm{m}$ in diameter and $3.5 \mathrm{~m}$ in depth, with a gently sloping bottom. More than $200 \mathrm{~g}$ of meteorite fragments have been collected here. It is not allowed anymore to collect samples from this well preserved crater.

The shape of Crater 4 has been strongly affected by geological excavations. Initially it was bowl-like, oval in shape and 14-20 m in diameter. On the distorted bedrock surface of its bottom, a funnel-shaped trace of the impact was discovered (Reinwaldt, 1928); it has provided valuable information about the parameters of meteorite fall. Unfortunately, this trace, too, has been deformed as a result of later excavations. The largest number of meteorite fragments was found at the crater bottom itself, 3-4 $\mathrm{m}$ away from the impact trace. Powdered dolomite from $20 \mathrm{~cm}$ beneath the crater bottom has yielded a $\mathrm{Tl}$ age of $5.4 \pm 0.6 \mathrm{ka}$ and a similar sample from a depth of about $55 \mathrm{~cm}$ yielded an OSL age of $1.55 \pm 0.20 \mathrm{ka}$. These data can be interpreted as a decrease with the depth of the bleaching effect.

Crater 5 also has been affected by excavations, and is presently overgrown with bushes. Its original shape resembled a flat bowl with a maximum diameter of $13 \mathrm{~m}$ and depth of 3 $\mathrm{m}$. In some places, fragments of the crater rim have been preserved. On the bottom of this crater, too, a trace left by the impact is visible. This crater yielded the biggest meteorite fragment ( $38.4 \mathrm{~g}$, including a lamina of rust). The crater was not sampled for TL dating.

Crater 6 was discovered near the road from Masa to Putla, $450 \mathrm{~m}$ to the North-West of the main crater. Its diameter is $26 \mathrm{~m}$ and depth $0.6 \mathrm{~m}$. It has been deformed due to its location near the road embankment, but numerous meteorite fragments have been found here. Only in 1963, A. Aaloe recovered $150 \mathrm{~g}$ of meteorite fragments (Tiirmaa, 1994). The crater was not sampled for TL dating.

Crater 7 is located south of the main crater. Its diameter is $15 \mathrm{~m}$, and it is somewhat over $2 \mathrm{~m}$ deep. Its shape resembles an irregular quadrangle. Excavations have been carried out in this crater and abundant me- 


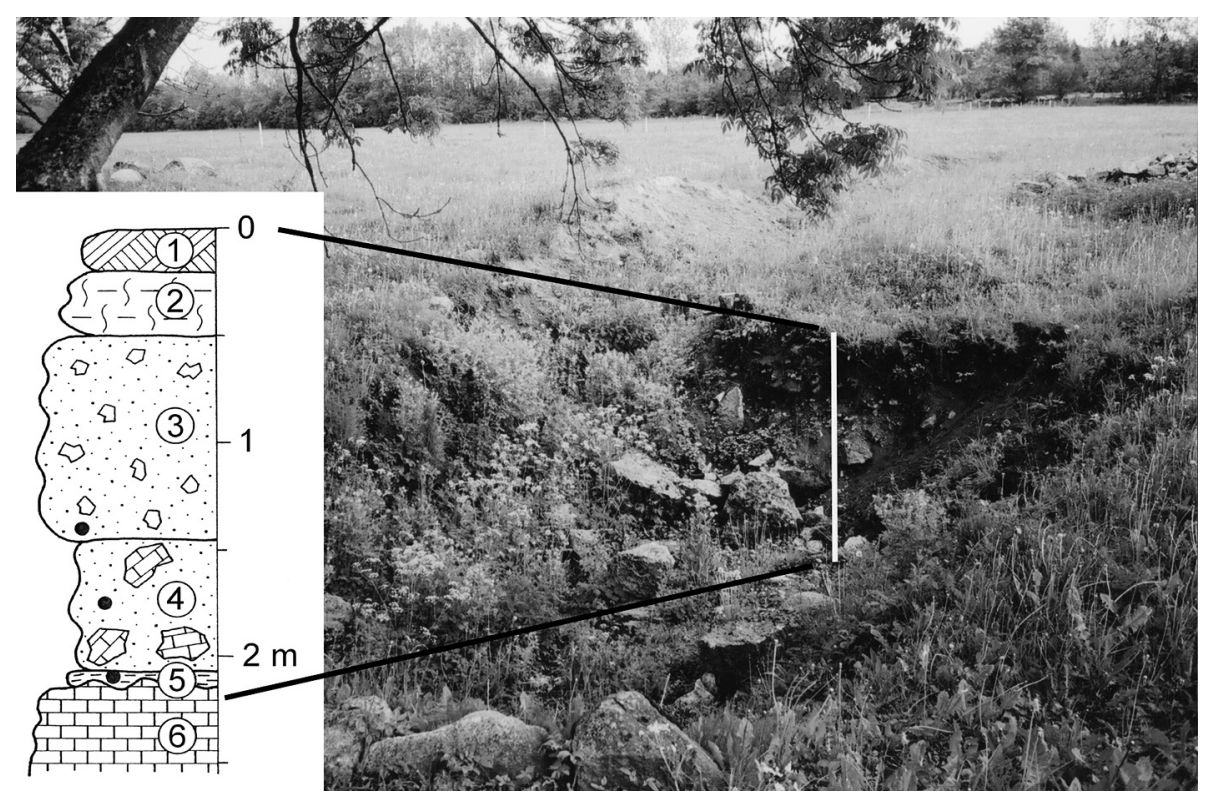

Fig. 6. Crater No 7 and its sedimentary infilling. 1 - humus layer; 2 - mineral sediments with dispersed organic matter; 3 Quaternary sediments with medium and fine gravel of Silurian dolostone; 4 Quaternary sediments with coarse gravel and blocks of Silurian dolostone; 5 - silt; 6 - Silurian dolostone.

teorite fragments have been collected. Two samples of the crater infilling were taken in 2005, but they have not been dated yet. The Silurian dolomite floor was encountered during the sampling at a depth of $\sim 175 \mathrm{~cm}$. One year later (2006), three samples of the crater infilling material were collected for TL and OSL analyses from $\sim 210 \mathrm{~cm}$ deep (see Fig. 6). The obtained result for the thin layer of siltyloamy sediments $(2-10 \mathrm{~cm}$ thick) from this depth (immediately covering the solid Silurian dolomite) is $10.20 \pm 0.46 \mathrm{ka}$ (Gd TL 929). This outcome is difficult to interpret. The thin silty-loamy layer can be attribute to one of latest Baltic floodings of the area. The question remains nevertheless whether this material in situ. Another possible interpretation is the influence of Silurian strata (cf. Stankowski et al., 2007). The luminescence data of two samples consisting of a mixture of shattered Silurian dolomite fragments and the Quaternary sedimentary crater infilling yield data, for a depth of $\sim 175 \mathrm{~cm}$, of $7.09 \pm 0.34 \mathrm{ka}$ (Gd TL 928), and, for a depth of $\sim 140 \mathrm{~cm}$, of $7.16 \pm 0.41 \mathrm{ka}(\mathrm{Gd}$ TL 927). These results seem to prove an Early Holocene crater age. The conclusion of the present authors is that the dates $\sim 7000$ years BP indicate the moment of sedimentary infilling, which must have started almost immediately after the creation of the crater.

\section{Why the Saaremaa features deserve the establishing of a geopark}

Saaremaa Island is of interest not only from a geological and morphological point of view (as detailed above), but the island has also a rich flora, some important faunal characteristics (the island is positioned within the east-Atlantic path of birds) and beautiful (and sometimes rare) landscapes (Kään et al., 2002). Examples of the latter are the alvars. These are areas on a limestone plain with a very thin soil horizon or no soil at all. The carbonate rocks which formed hundreds of millions years ago, make this substratum suitable for habitats and species communities that cannot exist elsewhere. During dry seasons, the soils (where present) dry down to the bedrock, whereas rainfall changes these areas into temporary ponds (since the limestone base prevents the water from running off). Winter winds frequently blow off the snow cover from open alvars, leaving the ground barren. The combination of these extreme conditions has led to the formation of unique ecosystems and specialized plant communities which have accustomed to calcareous and dry habitats. Alvars have thus actually become a meeting place of 
plants from different climate and vegetation zones. On the alvars of Saaremaa, plants grow that are common in southern Siberia, and other plants that are widely spread in the steppes of south-eastern Europe. One of the most fascinating aspects of alvars is that they are among the most species-rich small-scale communities in the world. Up to 49 species of vascular plants have been found growing on a patch of land of only $1 \mathrm{~m}^{2}$; on larger patches, their number may exceed even one hundred.

Also $80 \%$ of the plant species found in Estonia are represented on Saaremaa, where, altogether, 1200 species of vascular plants occur; about 120 species are rare ones which have received special protection status (Kään et al., 2002).

During last decade, 66 geoparks have been established in 19 countries, and geotourism has developed worldwide in recent years. Comparison with the existing geoparks supports our view that the Island of Saaremaa is worth to become included in this list, particularly since the island houses, in addition to the natural treasures, numerous architectural monuments, such as medieval churches and Kuressaare Castle. Saaremaa thus fulfills the requirement that areas appointed as geoparks should have a geological, archaeological, cultural and environmental heritage of special importance, rarity or beauty. The task of a geopark is (1) to bring this heritage to life for visitors and local people, (2) to raise awareness of the significance of the landscapes and geological objects, and (3) to explain how they were formed. Established in 2000, the European Geoparks Network aims to protect geodiversity, to promote geological heritage to the public, and to support sustainable economic development of geopark territories through the development of geological tourism. At the same time, it is necessary to increase the geological knowledge through scientific research.

\section{Final remarks}

The geology of Saaremaa has been rather well studied, but many problems of topical interest are not yet solved and need scientific cooperation between specialists from different countries. Several international bilateral working teams from France, Poland, Hungary, Sweden, Denmark and other countries have investigated the morphology, structure and age of the Kaali craters and the Quaternary geology of Saaremaa. Good results have been obtained through the common 'Extraterrestrial material and impact structures in Poland and Estonia' project, coordinated by the Estonian Academy of Sciences (implemented by the Institute of Geology at the Tallinn University of Technology) and the Polish Academy of Sciences (implemented by the Institute of Geology of the Adam Mickewicz University).

The joint collaborative 'Fostering geotourism on Central Baltic islands' project (20072013, funded by ERDF through Central Baltic INTERREG IV and implemented by the Department of Earth Sciences at the Uppsala University in Sweden and by NGO Geoguide Baltoscandia in Estonia) aims at preparing a solid basis for the development of nature tourism on major central Baltic islands, including Saaremaa.

In recent years, steps forward have been set in Kaali. A visitor centre, including a museum of meteoritics and local geology, a conference hall, guest rooms, a souvenir shop, and an employees office, have been opened in Kaali in the summer of 2005. During the last decades, much work has been carried out in the crater field. The craters have been cleaned from rubbish, steps have been built to study the structure of the small craters, shrubs have been cut down, access to the main crater is scheduled, and a sightseeing platform has been built. Some 50,000 people visit the crater annually and human impact on the craters remains consequently large.

\section{References}

Kään, H., Mardiste, H., Nelis, R., Pesti, O. (Eds), 2002. Saaremaa I. Loodus. Aeg. Inimene. Tallinn, Eesti Entsüklopeediakirjastus, $623 \mathrm{pp}$.

Karukäpp, R., Eltermann, G. \& Raukas, A., 2002. Liustikutekkelise pinnamoe kujunemine [Formation of the glacial topography]. [In:] Kään, H., Mardiste, H., 
Nelis, R. \& Pesti, O. (Eds): Saaremaa I. Loodus. Aeg. Inimene. Tallinn, Eesti Entsüklopeediakirjastus, 52-56.

Marini F., Raukas A. \& Tiirmaa R., 2004. Magnetic fines from the Kaali impact-site (Holocene, Estonia). Preliminary SEM investigation. Geochemical Journal 38, 211-219.

Märss, T., Soesoo, A. \& Nestor, H. (Compilers), 2007. Silurian cliffs on Saaremaa Island. Tallinn, MTÜ GEOGuide Baltoscandia, 32 pp.

Meri, L., 1976. Hõbevalge [Silver white]. Tallinn, Eesti Raamat, $488 \mathrm{pp}$.

Moora, T., Raukas, A. \& Kestlane, Ü, 2008. Kaali meteoriidi peakraatri setetest [On deposits of the Kaali main crater]. [In:] Lang, V. (Ed.): Muinasaja teadus 17. Loodus, inimene ja tehnoloogia 2, 209-229.

Perens, H, 2002. Tektoonika ja aluskord. Pealiskord [Tectonics and crystalline basement. Bedrock]. [In:] Kään, H., Mardiste, H., Nelis, R. \& Pesti, O. (Eds): Saaremaa I. Loodus. Aeg. Inimene. Tallinn, Eesti Entsüklopeediakirjastus, 21-36.

Raukas, A., 1995. Estonia - a land of big boulders and rafts. Questiones Geographicae, Special Issue 4, 247-253.

Raukas, A., 2004. Distribution and composition of impact and extraterrestrial spherules in the Kaali area (Island of Saaremaa, Estonia). Geochemical Journal 38, 101-106.

Raukas, A., 2009. When and how did the continental ice retreat from Estonia? Quaternary International 207, 50-57.

Raukas, A. \& Stankowski, W., 2005. Influence of sedimentological composition on OSL dating of glaciofluvial deposits: examples from Estonia. Geological Quarterly, 49, 463-470.

Raukas, A., Punning, J.-M., Moora, T., Kestlane, Ü. \& Kraut, A., 2005. The structure and age of the Kaali main crater, Island of Saaremaa, Estonia. [In:] Koeberl, C. \& Henkel, H. (Eds): Impact tectonics. Heidelberg, Springer, 341-355.

Reinwaldt, I., 1928. Bericht über Geologische Untersuchungen am Kaalijärv (Krater von Sall) auf Ösel. Mit Beiträgen von A. Luha. Loodusuurijate Seltsi Aruanded 35, 30-70.

Reinwald, I., 1938. The finding of meteorite iron in Estonian craters. A long search richly rewarded. The Sky Magazine of Cosmic News 2, 6-7.

Stankowski, W.T.J., Raukas, A., Bluszcz, A. \& Fedorowicz, S., 2007. Luminescence dating of the Morasko (Poland), Kaali, Ilumetsa and Tsõõrikmäe (Estonia) meteorite craters. Geochronometria 28, 25-29.

Tiirmaa, R., 1994. Kaali meteoriit [The Kaali meteorite]. Tallinn, Eesti Teaduste Akadeemia Geoloogia Instituut, 103 pp.

Uścinowicz, G., 2008. Materia pozaziemska w otoczeniu kraterów meteorytowych Kaali (Estonia) [Extraterrestrial material from the surrounding of the Kaali meteorite craters (Estonia)]. Geologos 14, 211-219.

Veski, S., Heinsalu, A., Kirsimäe, K., Poska, A. \& Saarse, L., 2001. Ecological catastrophe in connection with the impact of the Kaali meteorite about 800-400 B.C. on the island of Saaremaa, Estonia. Meteoritics \& Planetary Science 36, 1367-1375. 